\title{
TOWARDS LIVING WITH MEANING AND PURPOSE: SPIRITUAL PERSPECTIVES OF PEOPLE AT WORK
}

\author{
DUSHIELA LALA MOHAN \\ KOOS UYS \\ jsu@rau.ac.za \\ Department of Human Resource Management \\ University of Johannesburg
}

\begin{abstract}
It seems that many people who are seeking meaning and purpose in their lives, are exploring spirituality as a way of providing greater levels of understanding of their life journeys. The focus of this research was to ascertain the meaning and purpose that spirituality gives to peoples' lives. This study was based on interviews conducted with ten professionals at middle and senior management levels, in a South African Financial Services company. A thematic analysis approach was used within the qualitative research paradigm. Respondents indicated through various themes, that having a spiritual perspective in life, helps them create meaning and purpose in their lives.
\end{abstract}

\section{OPSOMMING}

Dit wil voorkom of baie mense wat na sin en betekenis in hulle lewens soek, die moontlikhede van spiritualiteit verken as ' $n$ wyse om hoër vlakke van insig in hul lewensreise te bewerkstellig. Die fokus van hierdie navorsing was om vas te stel watter sin en betekenis spiritualiteit aan mense se lewens gee. Hierdie studie is gebaseer op tien onderhoude wat met professionele persone op middel en senior bestuursvlakke in 'n Suid-Afrikaanse dienstemaatskappy gevoer is. 'n Tematiese ontledingsbenadering binne die kwalitatiewe navorsingsparadigma is gebruik. Respondente het aan die hand van 'n verskeidenheid temas aangedui dat 'n spirituele lewensperspektief tot sin en betekenis in hul lewens bydra.

The wellbeing of a nation is determined by examining factors such as the unemployment rate, poverty levels, the distribution of wealth, levels of corruption, crimes against humanity to name but a few. If these factors were examined to determine the state of wellbeing of the world, most people would agree that the world is not in a good state. It seems that we have reached a stage of human evolution where we need to evaluate the state of our being in the world. Many people would agree with Fox (1994) when he states that the scientific, materialistic paradigm that we've inherited from the past, has brought great misery to the world. The social, economic and political systems that are part of our current reality, are achieving little in terms of enhancing our world. A critical look at twentieth century organisational life shows that there have been benefits of increased wealth for some, growth and technology. These benefits however, according to Biberman, Whitty and Robbins (1999), are often at the expense of "humanity, soul and nature".

Literature reflects that as an increasing number of people are beginning to question the status quo of humankind in the universe, they are also becoming disillusioned with organisational life. Many individuals in the workplace are reexamining the meaning of work as well as starting to question the meaning and purpose of their life. Bruzzese in Cacioppe (2000) states, employees are not only seeking a good salary or benefits, but they also want to be in a job that adds value to their lives, spiritually or otherwise. It has been reported by various researchers that many people after getting established within a family and career during adult life, keep asking questions such as Who am I, Why am I here, Where am I going and What is my purpose in life? (Milanovich and McCune, 1996). These seem to be the type of questions that revolve around establishing a well defined identity around one's existence or purpose in life. According to Frankl, the inability to establish such an identity may produce a condition called existential anxiety (Bruno, 1974). A way of preventing this type of anxiety may be for people to express more of who they are at work as well as finding a way to be authentic in what they do and how they do it. Mitroff and Denton in Cacioppe (2000), suggest that people need to question and reshape their role within the organisation and reassess the meaning and value of their work. Biberman et al. (1999) state that on our journey through our work lives we must find ourselves, and our true work.

As a response to the current state of the universe, many people have realized that the status quo needs to be challenged. If the scientific, materialistic paradigm of the past did not create a world to be proud of, what types of alternatives are people starting to explore, to bring about change in the world? According to Cacioppe (2000) there has been a rapid and substantial interest over the last 30 years in the exploration of a wide range of spiritual paths including yoga, Buddhism, Toaism, Vedanta, and meditation. This interest has spilt over into organisations, according to Biberman et al. (1999), where organisations worldwide have begun to show an increased interest in spirituality and spiritual values. The search for spirituality and the interest in integrating spirituality with everyday work life has gained momentum during the 1990s (Brandt, 1996). The desire for personal fulfilment combined with a deep personal spiritual experience has resulted in many people wanting to bring spirituality into all important aspects of their lives. Interviews done with senior executives and human resource managers by Mitroff and Denton (Cacioppe, 2000), described spirituality as meaningful and purposeful in itself and therefore as an end in itself. Although there has been an increased interest in spirituality by organisations, the spiritual journey for many employees happens outside the workplace. Consultants and business writers are urging organisations to pay more attention to spirituality, as it is not only individuals but organisations as well, that are on a spiritual journey.

If emerging trends seem to indicate that spirituality is playing an increasingly predominant role in some people's lives, what does this mean for organisations? If spirituality is an integral part of being human, and employees are encouraged to bring their "whole" self to work, what role does spirituality play in the workplace? It is only in gaining a greater understanding of spirituality, that we can begin to address these kinds of questions. The focus of this research is to assist with gaining greater clarity on the role that spirituality plays in people's lives. This understanding can help us get a better perspective of how spirituality spills over into the workplace. 


\section{RESEARCH DESIGN}

\section{Research approach}

In exploring the meaning and purpose that spirituality gives to people in their life, an interpretive approach was used. This approach is characterized by a particular ontology, epistemology and methodology. Researchers working in this tradition assume that people's subjective experiences are real and should be taken seriously (ontology), that we can understand others' experiences by interacting with them, and listening to what they tell us (epistemology), and that qualitative research techniques are best suited to this task (methodology) (Terre Blanche \& Durrheim, 1999). This approach enables the researcher to study phenomena in its natural context. The researcher would do this by entering the research setting with the necessary care and engaging with research participants in an open and empathic manner. In addition, Creswell as cited in Parker and Roffey (1997) states that the operating values (axiological assumptions) are that qualitative researchers act in a value-laden and biased fashion. The language style (rhetorical assumptions) of qualitative researchers is to use personalized, informal, and context based language.

\section{RESEARCH METHODOLOGY}

\section{Participants}

Since each person is a spiritual being, it was not considered necessary to include only "experts" in this study. Everybody's viewpoint or experience is relevant. Ten professionals, at middle and senior management levels, working in a Financial Services organisation were interviewed. There were two males and eight females and the participant group was a racially mixed group. All participants were in the age range $30-45$.

\section{Methods of data gathering}

As this study is a qualitative one, semi structured, face to face interviews were used to gather data. Individuals were asked to relate to the interviewer what gives them meaning and purpose in life as well as what detracts from meaning and purpose in life. They were also asked what does spirituality mean to them and what role does spirituality play in their life.

Qualitative interviewing emphasizes the active participation of the interviewer and the importance of giving the interviewee voice (Rubin \& Rubin, 1993). As participants responded to the questions posed to them, they were probed for more information where relevant. Qualitative interviewing requires intense listening, a respect for and curiosity about what respondents say.

Being interested in the topic of spirituality helped the researcher to be open to new meanings and perspectives. Care was taken to ensure that the researcher's perspectives of spirituality did not influence the thinking of the respondents.

\section{Capturing the data}

All interviews were audio taped with the respondents' permission. Interviews were then transcribed and checked against the tape recording.

\section{Treatment of the data}

Thematic analysis was used to examine the data. This is a general methodology of analysis, linked with data collection that uses a systematically applied set of methods to generate information about a phenomenon. This type of research is directed towards making sense of the data collected and giving them a structure, with a view to determining their meaning and significance for the participants, researchers and readers (Miles \& Huberman, 1994). Transcribed interviews were read to get an overview of the responses. Coding strategies were employed which resulted in breaking down the data into distinct units of meaning and first level codes were assigned to participant responses. These first level codes were then clustered into themes. The themes were based on phrases or concepts used by the participants. The data were again reviewed to ensure that the content fit the identified themes. The themes were reworked until all coded data fit into the identified themes.

Objectivity as a methodological norm in qualitative studies, refers to letting the object speak and not distorting the message, according to the Munchhausen conception of objectivity as cited in Coutinho (1992). This means that the mental attitudes of the researcher must be objective in terms of creating a balance between involvement and detachment. Care was taken to ensure objectivity by the researcher in this process. This was done throughout the interview process as well as by taping all interviews.

Reliability of the study was enhanced through audio taping all interviews and submitting data to the study leader to check for accidental distortions

Validity in this study was enhanced by audio taping and transcribing each interview in its entirety. During the analysis process a period was set aside in which data were arranged and interpreted without making use of special knowledge of the literature. According to Coutinho (1992), this approach would have also enhanced the validity of this study. Data were also submitted to the study leader to check the validity of the emerging themes.

Through the data analysis process, the following nine themes emerged:

- Relationship with higher beings

- Making sense of life

- Acknowledging and nourishing the inner world

- Living authentically

- Finding meaning and purpose through work

- Our relationship with other people

- Living a balanced life

- Organisations as spiritual entities

- Our role in creating the future.

\section{RESULTS}

The participants' interviews will now be discussed in relation to the emerging themes. The identities of participants have been changed to ensure confidentiality. Nine of the ten respondents considered themselves spiritual. One respondent reported that she is not very religious and she also has not given much thought to spirituality. She describes herself as "pragmatic" and is more concerned with the here and now, and does not believe that there is another being on another plane controlling events on earth.

\section{Relationship with higher beings}

The majority of respondents made a distinction between religion and spirituality. Spirituality was described as encompassing a personal relationship with a higher being, while religion was described as more ritualistic. Nine of the ten respondents reported a relationship with a higher being. Some people reported a relationship with more than one higher being. Pam reported a relationship with her ancestors who, she said, "wanted me to become a sangoma" because she has a high level of spiritual awareness.

Kate believes that her level of spiritual awareness helps her to connect with "angels and guides" that exist on a non-physical plane. Through these connections she accesses information that helps her with decision making in all areas of her life. She cites the following work related example: "when I go into a meeting, I call on the guardian angels and souls of all present, to ensure that all decisions made will be aligned to the greatest good of all". Kate also states that being spiritually aware, helps her to "see God in everything". 
A relationship with God, a higher power or other mystical beings, is reported to be a source of strength for people. It creates a belief in individuals that they would be able to cope with any adversity in life. According to Valerie, "this relationship gives me an assurance that the world is in good hands". It allows Joyce to trust that "whatever happens, I will be fine because there is something greater that is taking care of me". Dorothy reports that it gives her a certain perspective that helps her deal with life. It also provides her with a set of values that guides her behaviour and helps her to look beyond material things.

Most respondents described their relationship with a higher being as a personal relationship which is a two way communication process. Dorothy states that "God talks to us through various ways. It may be through other people, a thought or a book".

\section{Making sense of life}

According to Kate spirituality gives her a certain perspective, which allows her to distinguish between "important and non important issues". It helps her to see the "bigger picture" in life, and consequently she is not unnecessarily absorbed by petty issues. A spiritual perspective encourages her to become more resilient. She believes that "everything happens for a reason and you need to discover the lesson that needs to be learnt from whatever happens".

Yasheen stated that being spiritual gives him a "higher level of awareness" in life, and it also helps him to differentiate between important and petty issues.

Dorothy believes that life is a "journey of growth and development". She feels that a spiritual perspective helps give her clarity on why she has certain experiences and what the lesson is for her growth. She believes that an individual will continue to experience certain types of events, until the required learning has taken place.

Joyce feels that since becoming more spiritually aware after the death of her mother, she is more "open to experiences and possibilities". She celebrates life more and looks for the positives in life.

Naseema opened herself to new experiences and to new challenges after conquering cancer. She also believes that "if you are open to change in your life, change will come your way. There will be no need for change management as you will be able to see the positives in the change".

\section{Acknowledging and nourishing the inner world}

For Yasheen, an important aspect of spirituality is connecting to "one's inner world". Valerie also believes that spirituality is about delving deep within yourself. Kate keeps in touch with her higher self or her soul self through meditation.

Both Naseema and Pam believe that your inner self determines your outer self. Therefore it is important to nurture your inner self, so that your interactions with the outside world, are more positive. Joyce reported that she is guided by her gut instinct in living out her purpose.

\section{Living authentically}

Respondents felt that from a spiritual perspective it is important to live authentically. Kate described this as "being able to express your whole self at work without having to worry about what other people may think of you". She also says that all decisions that you take should be "aligned to your truth". She reported that spirituality underlies every decision that she makes, every action, word and thought. Joyce felt that to live a meaningful life she has to be "true" to herself. Paul felt that to live a meaningful life, it is important for him to be able to "integrate the work as well as the non-work" aspects of his life. Valerie feels that she is able to reach her maximum potential when she is allowed to express herself honestly and be upfront with people. For her, spirituality is about doing the right thing and making the right choices. Values are very important in guiding behaviour at work. Dorothy wants to be able to express herself freely and be in an environment where she can behave in a way that allows her to be "true" to herself.

\section{Finding meaning and purpose through work}

Nine of the ten respondents believe that life is not random. They believe that all people have been created for a specific purpose. Most respondents said that work that gave them meaning and purpose was work that made a positive contribution to other peoples' lives.

Dorothy believes that for each role that we have in life such as wife, mother, friend or colleague, there is a purpose linked to that role. In this scenario, purpose is wider than a career or a work related role.

Kate mentioned that she wanted to live out her life purpose by moving to the healing profession. The realization dawned on her that she would be able to do healing work while still performing the role of a senior manager. She believes that she initiates a process that encourages people to experience life changing events that give them the opportunity to heal themselves on a deeper level.

Paul mentions that part of the work that we need to do is healing work. He believes that in life and in organisations we are called upon to be "wounded healers". All of us have wounds. We need to realize what these wounds are and then work at healing them. Once we've healed our own wounds, we can assist other people to heal similar wounds in themselves. The purpose of human life seems to be, to individually and collectively evolve to the greatest level of wholeness.

All people are spiritual beings at different places in their life journeys. The theme of this life journey, according to most respondents, is one of growth and development. And as we make our journey along the path of increasing spiritual enlightenment, life becomes more meaningful.

\section{Our relationships with other people}

An important part of spirituality is our relationship with other people. All respondents stated that they would like to enhance the quality of life of other people.

Kate believes that from a spiritual perspective, "all people are equal on a soul level". This perspective encourages one to love people unconditionally and accept them for who they are and not only for what they contribute to the bottom line. Each person is on his own journey in life and he should be supported unconditionally.

Paul feels that from a Western perspective, in organisations, "we only have a commercial relationship". He feels that the value of people resides only in their levels of production and it is easy for people to become "useless" in organisations. He believes that a spiritual perspective helps him to "accept people for who they are, with all their faults, errors and idiosyncrasies, and not only for what they contribute to the bottom line". He believes that in organisations people are quick to reject failure. He claims that we need to accept that all people make mistakes and we need to learn from these mistakes. We need to accept people for who they are and not focus so much on who they are not. The respondent believes that in organisations there is an expectation that people should be perfect and that there is no room for error. He believes that a spiritual perspective encourages him to accept that nobody is perfect, that we are all on a journey, and we do not have all the answers.

Joyce does not believe in judging people. She always sees an opportunity for relationship building, even in conflict 
situations. She believes that spirituality allows her to see the good in people and to forgive people who hurt her, so that she can move past it.

Pam feels that relationships with other people are very important to her because they teach her a great deal about herself. A valuable lesson for her was learning to love herself and finding her own happiness within, before she could find this in a relationship with another person.

Yasheen believes that spirituality helps people to have greater control over their minds as well as their egos. It helps people overcome anger, greed and lust and therefore impacts positively on relationships.

\section{Living a balanced life}

Paul believes that fostering the spiritual side of him keeps him healthier. Dorothy wants to create a balance in her home and career within the realm of spirituality.

\section{Organisations as spiritual entities}

Kate believes that "an organisation also has a soul and its journey is to become the best that it can be, according to the highest good". This relates to an organisation having a positive impact on its customers' lives, the lives of its staff as well as the community in which it functions.

Yasheen sees spirituality in organisations where there is care and concern for people and community work is done for the upliftment of people.

\section{Our role in creating the future}

Naseema believes that our minds are very powerful and we can create good or bad in our lives, depending on the quality of our thoughts. She believes that if you put out a plan for your life to the universe, you will be given opportunities to make your plan a reality. She has experienced creating her reality through meditation, prayer and visualisation. She also believes that trust is a very important part of this process. Pam believes that if you visualize your goals and you focus on them strongly, you will achieve them. Kate feels that prayer is important as well as "setting intentions for your life".

\section{DISCUSSION}

In conducting a literature survey on the theme of spirituality, support was found for the themes that arose out of this study. A discussion of the various themes will now be undertaken.

One of the challenging aspects about spirituality is that it seems to hold different meanings for different people, making it difficult to give it a universal definition. The use of the term spirituality in the workplace seems to evoke responses ranging from fear, scepticism, and confusion to great enthusiasm about the concept (Condemi, Ferguson, Milliman and Trickett, 1999; Freshman, 1999). Mitroff and Denton in Cacioppe (2000), define spirituality as the basic desire to find ultimate meaning and purpose in one's life. Ashmos and Duchon (2000) define spirituality at work as the recognition that employees have an inner life that nourishes and is nourished by meaningful work that takes place in the context of community.

Spirituality is often seen in the same context as religion, with particular beliefs, moral rules and traditions. Spirituality however is different from organized religion as it is not formal or structured. Spirituality is accessible to each individual irrespective of a religious orientation. Spirituality is above and beyond any specific religious denomination and focuses on the common principles and truths that each religion offers. Perle in Laabs (1995) states that spirituality is not about converting people, nor is it about influencing peoples' belief system. It's about knowing that we're all spiritual beings having a human experience. It's about knowing that every person has within him or her, a level of truth and integrity and that we all have our own divine power.

Although spirituality differs from religion, it acknowledges the existence of a higher power. Each individual would relate to this higher power in his own way. When discussing spirituality, concepts such as sacred, divine or otherworld should not be excluded as spirituality implies a relationship with something intangible beyond self (Fairholm, 1996; Cacioppe, 2000). This is a guide for values and meaning as well as a way of understanding self and the world. McCormick (1994) believes that the common themes of spiritual traditions guide us to live in harmony with the Divine.

Many of the respondents view life as a journey of growth and development and believe that we grow through the choices that we make in life. Growth comes from choices that are based on life rather than fear. All life events are seen in perspective of a spiritual journey and this is what gives people meaning and purpose in their lives. The purpose becomes to deal with each life event as a learning opportunity and to evolve on the soul's journey through life in terms of healing one's wounds and becoming whole (Redfield \& Adrienne, 1996; Zukav, 1991). When an individual is committed to meaningful living, it creates a framework from which life events can be interpreted and which provides an individual with specific purposes (Battlista \& Almond, 1973). Redfield and Adrienne also feel that our purpose as human beings is more than just survival in a physical or materialistic world. At a higher level, our purpose is to evolve spiritually through actions motivated by love. A way for humans to advance individually and collectively is through fully embracing who we are, following inner guidance and helping others rather than only working to advance our own interests. These authors believe that the ultimate goal for humanity is to merge the material and spiritual dimensions. They feel that living our purpose is more than identifying ourselves by occupation, educational class or worldly achievements. Living our purpose should be living in alignment with our head and heart, making a living joyfully by expressing our abilities and talents that help the common good. They believe that with this attitude in the workplace, people have a greater chance of feeling more centred, more creative and more fulfilled.

This study reflects that spirituality plays a large role in the respondents' lives. Each life is looked upon as a journey and each person is at a different place on their spiritual journey.

Fox (1994) states that human beings have both an inner life as well as an outer life, and that the nourishment of the inner life can lead to a more meaningful and productive outer life. For many, the inner life is understanding one's divine power and more specifically how to use that divine power to live a more satisfying outer life. Some people however are more aware of the inner life than others. People who engage in practices such as meditation, self reflection and prayer are more likely to be more sensitive to the inner life and also are more likely to be concerned about the relationship of the inner life to their work. A message from the literature on spirituality seems to be that we need to focus less on the external world and how we can control it, and more on the internal world where we impact on our level of consciousness (Redfield and Adrienne, 1996; Ashmos and Duchon, 2000). For Chopra (1994), spiritual awareness is increased by discovering the power of one's true or higher self. The more in touch an individual is with his higher self, the less fear, compulsion to control, or struggle for approval an individual has. When a person is in touch with his spirit or soul, he is unafraid of any challenge and recognizes that he is neither superior nor inferior to anyone else. As an individual gains more access to his true nature or accesses pure consciousness, he receives more creative thoughts, as the field of pure potentiality is also the field of infinite creativity 
and pure knowledge. It is through the individuation process, as introduced by Jung, that individuals achieve integration of the self and the full maturation of their potential (King \& Nicol, 1999).

Many respondents stated that it was important for them to be able to live out their values while being in an environment that allowed them to express themselves freely and honestly. LipsWiersma and Mills (2002) feel that current spirit at work literature often assumes that spirituality needs to be introduced to the workplace. These authors argue that spirituality is already present as many individuals have spiritual beliefs but struggle to articulate or enact these beliefs at work. One way of integrating spirituality in the workplace is through introducing values that enable the human spirit to grow and flourish. These values include truth, trust, integrity, freedom, justice, creativity, collective harmony, intelligence, being true to oneself, deeper meaning and higher purpose. These values often reflect a desire to make a difference and help create a more meaningful world. These values are displayed through teamwork, serving others and acting in the best interest of the organisation (Butts, 1999; Fox, 1994; Milliman et al., 1999; Neal, 1997). Fox also believes that if an individual does not live his true values, it could lead to spiritual starvation.

People who consider themselves spiritual believe that there is a master plan for the universe. They believe that life is not random and that every human being has been created for a specific purpose in life. When considering one's purpose in life people often think about this purpose as something that exists out there, waiting to be discovered. An individual's purpose is generally perceived as a namable occupation, which once he has moved into, will be the start of his real life (Redfield \& Adrienne, 1996). Traditional career development theories are focused on helping an individual to find a match between himself and the type of career that will give him satisfaction or meaning. An individual's purpose therefore is commonly seen as the work that he needs to do to earn a living. Maslow talks about isomorphism which refers to a mutual selection between the person and his self actualizing work, which he also refers to as his call or vocation. One must respond to one's fate or destiny or else according to Maslow, real happiness would be elusive (Maslow, Stephens, \& Heil, 1988).

A spiritual perspective informs us that our purpose may not be solely packaged as a career. An individual's purpose may be to learn to be more compassionate in responding to all beings. An individual's purpose may be to mentor one special child or create an industry. Many people experience levels of frustration at not knowing what their life purpose is. It is not helpful to assume that until you find your purpose, your life is on hold or is insignificant. The present moment is the only moment an individual has to fully touch and be touched by life. Individuals should look for the purpose of each day's events and create an intention that will help them discover their life purpose. The guidance for each individual in discovering their unfolding purpose, lies within them (Redfield \& Adrienne, 1996). This view is shared by Chopra (1994) who believes that as each individual discovers more about his true or higher self, he discovers more about his purpose in life.

Thomas Aquinas, the thirteenth century saint and theologian as cited in Fox (1994) stated that the quality of an individual's life is linked to the quality of the work that he does. He said that we should not separate life and livelihood as they both originate from the same source, and they are both about living in depth, living with meaning, purpose, joy and a sense of contributing to the greater community. Spirituality in the workplace is about bringing life back to livelihood.

Fox also feels that a paradigm shift is required in the way that we think about, talk about and do work. He makes a distinction between a job and work. A job may be what we do to earn money while work comes from inside out. Work is the expression of our soul, our inner being and that which enables us to be of service to others in the community. Biberman et al. (1999) believe that there is a sacred dimension to daily work.

Spirituality also distinguishes between outer work and inner work. Outer work is work that takes place outside ourselves while inner work is work that we need to do within ourselves. The aim of inner work is to strive for wholeness and this will help humanity to find solutions for issues such as violence, selfdestruction, oppression, racism, sexism, and various forms of abuse. If we are able to bring inner and outer work together and create a spiritual centre from which to work, no work as long as it is good work, will be alienating (Fox, 1994).

Many respondents stated that it was important for them to have a positive impact on other people. The quality of relationships was mentioned as an important factor when dealing with people. According to Miller, as cited in Milliman et al. (1999), personal relationships that provide caring, nurturing and cooperation are all considered important aspects of spirit at work. Mitroff and Denton state that spirituality is inextricably connected with caring and love (Cacioppe, 2000).

Dorothy mentioned that it was important for her to create a balance in her life, while Paul felt that when he fostered the spiritual side of him, he felt healthier. When looking at the model of wellness and prevention proposed by Witmer and Sweeney (1992), balance becomes important for wellness and so does a focus on the spiritual aspect of a person. The major themes of the model relate to wholeness in mind, body, spirit and community. Witmer and Sweeney state that we should not only consider what is required for adequate health but should focus on what is necessary and desirable for optimum health and functioning. In this model the concept of wellness describes the total person approach for improving the quality of life in proactive and positive ways.

The true purpose of business and work in society is being debated. Pope J. Paul II, cited in Fox (1994) states that the purpose of an organisation is not simply to make a profit but should be found in its existence as a community of people. He stated that while profit is a regulator of the life of a business, other human and moral factors in the long term are at least equally important for the success of a business. Research done by Collins and Porras (Milliman et al., 1999) show that all visionary companies that have posted exceptional long term financial performance have as their primary goal something other than maximizing profit. Their goals reflect an approach that contributes to the greater good. Some writers have spoken about the "soul" of a business. As cited in Lichtenstein (1997), Chappel described the soul of a business as the essence that creates meaning for its leaders and members. According to Blanchard and O'Connor (Milliman et al., 1999), spiritual values represent the soul of the organisation and reflect its sense of spirituality and purpose.

Many of the respondents reported that they needed to be in an environment that allowed them to express themselves freely and which also valued them for who they are, for them to be able to maximize their potential. The "spiritual freedom model" proposed by Krishnakumar and Neck (2002), encompasses the concept of "spiritual freedom" where individuals in an organisation should be encouraged to express their own views of spirituality. They believe that spiritual enrichment would have positive outcomes such as intuition, creativity, honesty, trust, personal fulfillment and commitment. Burack (1999) suggests that organisations should provide nourishment for the individual's spirit by amongst others, giving him a sense of being in charge of his own destiny, as well as recognizing his creative accomplishments and performance. 
Organisations can accomplish this by creating a community in which their employees can thrive. Ashmos and Duchon (2000) describe a community, as a place in which one can experience personal growth, be valued for themselves as individuals and have a sense of working together. Lamont (2002) states that community occurs when there is a sense of well being, when each person and group feels valued and part of a whole, and when each is able to be most fully themselves while, paradoxically, being one with another. Community is ideally characterized by individuals being valued and diversity being celebrated. A community is a living, growing organism in which individuals themselves evolve. It is both a safe place and a challenging place in which people can be fulfilled. Literature reflects that the organisation acting as a community and having a cause or important purpose are central interrelated aspects of workplace spirituality (Milliman et al., 1999).

According to Dehler and Welsh (1994), organisations are places where people create meaning for themselves and have their meaning shaped. The suggestion is that people want to have something to believe in, have meaningful work, and feel like they can contribute to an organisational mission that makes a difference in others. An organisation that treats its employees as part of its community and emotionally engages them in a company purpose, which makes a difference in the world, will obtain a higher level of employee motivation and loyalty and higher organisational performance according to Brown as cited in Milliman et al. (1999). When individuals are aligned emotionally, their behaviour is motivated by the organisation's underlying purpose. Organisations now commonly write vision and value statements that not only provide direction for business operation plans but aim to motivate and inspire employees to be committed to a worthwhile purpose. Cavanagh (1999) believes that an executive who takes spirit seriously, will be able to more readily lead, and articulate a vision for the organisation.

Just as individuals have an inner life, so do communities and organisations. The aim of organisations should be to discover their inner power, which would allow them to balance their energies and transform them into more humane systems. The more aware an organisation is of its inner power, the easier it would be for it to evolve towards its highest and most creative possibilities (Biberman et al., 1999).

Quantum physics has provided us with the knowledge to understand the subatomic realm. This includes that invisible universe underlying, embedded in, and forming the fabric of everything around us. Quantum physics shows us that we are not as separate from the rest of the world as we once thought. We are not merely bystanders watching the world out there. An observer cannot observe without altering what he sees. Each of us has a part in creating reality. The distinction between the "in here" and the "out there" upon which science was founded, is becoming blurred. What is out there apparently depends upon what we decide in here (Zukav, 2001; Nascon, 1998). David Bohm as cited in Neal, Lichtenstein and Banner (1999) describes physical reality as an unbroken, seamless whole, where our perception of separateness is merely a habit of thought. Biberman et al. (1999) state that we need to be aware of the interconnectedness of all things.

The field of energy in which we live, and from which we create with our intention, is consciousness. It is both the creator and the uncreated. Chopra (1994) calls it the field of pure potentiality. Redfield and Adrienne (1996) state that what we want, exists first in our minds and hearts, and becomes a reality through holding that intention. If thought creates reality, then we must keep our intention focused on the positive outcome that we desire to happen. Upadhyaya (1995) suggests that co-creating loving, celebratory and just global realities for all life, and all ways of life, is humanity's most important task.

\section{Conclusion}

This study has shown that spirituality does play an important role in helping people derive meaning and purpose in their lives. The following important themes emerged from the study. Most respondents reported having a relationship with a higher being. The benefit of this relationship is the strength that people draw from it, to help them face adversity in their lives. People also communicate with a higher being and are open to receive guidance on issues that may need resolution in their lives. A spiritual perspective also helps respondents to make sense of life. It helps them to frame life events and to understand the significance of certain events in their life. The theme of the soul's evolution through a growth and development process also helps with understanding and coping with adversity in life. Another theme that surfaced in the study is gaining meaning and purpose through work. A distinction was made between inner and outer work and a belief was reflected that our inner world creates our outer reality. The implication is that we then need to do a great deal of inner work if our aim would be to collectively change the current status of the outer world for the better. For people to live a spiritual life, it is important for them to live an authentic as well as a balanced life. An environment that allows them to express themselves freely will be the one that fosters spiritual growth. The theme of acknowledging and nourishing the inner world also surfaced in this study. Some respondents nourish their inner world through meditation, reflection, contemplation and prayer. The theme of relationships was mentioned as an important one. From a spiritual perspective if all people are perceived to be equal on a soul level, it becomes easier to treat people with equity and fairness. The quality of relationships in organisations would benefit tremendously and less energy would need to be spent on conflict resolution. If individuals start to believe that they can impact positively on their future, we can start to have a concerted effort to change the world for the better. Organisations were also mentioned as spiritual entities whose focus should be to act in the best interest of their staff, customers and the communities in which they function.

The findings of this research study show that spirituality plays a definite role in peoples' lives. Spirituality is all embracing in that it impacts people on all levels and in all spheres of their lives. It cannot be confined to an individual's personal life nor can it be divorced from organisational life. To honour spirituality, organisations can start creating space for people to talk about spirituality. Conversations about spirituality would be a very powerful way of encouraging people to share their perspectives on this theme. A heightened level of group awareness or a raised level of collective consciousness within an organisation, could impact on the organisational culture in profound and positive ways.

If spirituality is all encompassing and already exists within organisations, then further research is needed to ascertain how organisational structures, policies, processes, procedures, roles and systems can tap in on a spiritual level to help orchestrate optimal human performance, contribution and satisfaction.

\section{REFERENCES}

Ashmos, D. \& Duchon, D. (2000). Spirituality at Work. Journal of Management Inquiry, 9 (2), pp. 134-45.

Battlista, J. \& Almond, R. (1973). The development of meaning in life. Psychiatry, 36, pp. 409-427.

Biberman, J., Whitty, M. \& Robbins, L. (1999). Lessons from Oz: balance and wholeness in organisations. Journal of Organisational Change Management,12 (3), pp. 243-254.

Brandt, E. (1996). Corporate pioneers explore spirituality. $H R$ Magazine, 41 (4), pp.82-88.

Bruno, F.J. 1974. Psychology: A Life Centered Approach. California: Hamilton Publishing Company.

Burack, E.H. (1999). Spirituality in the workplace. Journal of Organisational Change Management, 12 (4), pp. 280-292. 
Butts, D. (1999). Spirituality at work: an overview. Journal of Organisational Change Management, 12 (4), pp. 328-332.

Cacioppe, R. (2000). Creating Spirit at Work : re-visioning organisation development and leadership - Part I. Leadership and Organisation Development Journal, 21 (1), pp. 48-54.

Cavanagh, G.F. (1999). Spirituality for managers : context and critique. Journal of Organisational Change Management. 12 (3), pp. 186-199.

Chopra, D. (1994). The seven spiritual laws of success. Bantam Press: London.

Condemi, B., Ferguson, J., Milliman, J. \& Trickett, D. (1999). Spirit and community at Southwest Airlines : An investigation of a spiritual values-based model. Journal of Organisational Change Management, 12 (3), pp. 221-233.

Coutinho, D. (1992). Methodology for Management Specialists. Trends and Methods. Bruinsma, G.J.N. \& Zwaneburg, M.A. (ed). Muiderberg.

Dehler, G.E. \& Welsh, M.A. (1994) Spirituality and Organisational Transformation. Implications for the New Management Paradigm. Journal of Managerial Psychology, 9 (6), pp. 17-26.

Fairholm, G.W. (1996). Spiritual Leadership. Fulfilling whole-self needs at work. Leadership \& Organisation Development Journal, 17 (5), pp. 11-17.

Fox, M. (1994). The Reinvention of Work: A New Vision of Livelihood for our Time. Harper San Francisco, San Francisco, CA.

Freshman, B. (1999). An exploratory analysis of definitions and applications of spirituality in the workplace. Journal of Organisational Change Management. 12 (4), pp. 318-329.

King, S. \& Nicol, D.M. (1999). Organisational enhancement through recognition of individual spirituality. Reflections of Jacques and Jung. Journal of Organisational Change Management. 12 (3), pp. 234-243.

Krishnakumar, S. \& Neck, C. (2002). The "what", "why" and "how" of spirituality in the workplace. Journal of Managerial Psychology. 17 (3) pp.153-164.

Laabs, J. (1995). Balancing spirituality and Work. Personnel Journal, 74 (9), 60-9.

Lamont, G. (2002). The Spirited Business. Success Stories of SoulFriendly Companies. Hodder \& Stoughton: London.

Lichtenstein, B.M. (1997). Grace, magic and miracles. A "chaotic logic" of organisational transformation. Journal of Organisational Change Management, 10 (5), pp. 393-411.
Lips-Wiersma, M. \& Mills, C. (2002). Coming out of the closet: negotiating spiritual expression in the workplace. Journal of Managerial Psychology. 17 (3), pp.183-202.

Maslow, A.H., Stephens, D.C. and Heil, G. 1998. Maslow on Management. New York : John Wiley \& Sons.

McCormick, D.W. (1994). Spirituality and Management. Journal of Managerial Psychology, 9 (6), pp. 5-8.

Milanovich, N \& McCune, S. (1996). The Light Shall Set You Free. Athena Publishing : USA.

Miles, M. B. \& Huberman, A.M. (1994). Qualitative Data Analysis. Sage, Thousand Oaks, CA.

Nascon, L. (1998). Deepak Chopra. How to live in a world of infinite possibilities. Random House : London.

Neal, J. (1997). Spirituality in Management Education : a guide to resources. Journal of Management Education, 21 (1), pp. 121-139.

Neal, J., Lichtenstein, B.M.B, \& Banner, D. (1999). Spiritual perspectives on individual, organisational and societal transformation. Journal of Organisational Change Management, 12 (3), pp.175-186.

Parker, L.D. \& Roffey, B.H. (1997). Methodological themes. Accounting, Auditing \& Accountability Journal, 10 (2), pp. 212247.

Redfield, J. \& Adrienne, C. (1996). The Tenth Insight. Holding the Vision. Transworld Publishers : London.

Rubin, H.J. \& Rubin, I.S. (1993). Qualitative interviewing: The art of hearing data. London: Sage.

Terre Blanche, M. \& Durrheim, K(eds). (1999) Research in Practice Applied methods for the social sciences. University of Cape Town Press: Cape Town.

Upadhyaya, P. (1995). The sacred, the erotic and the ecological: the politics of transformative global discourses. Journal of Organisational Change Management, 8 (5), pp. 33-59.

Witmer, J.M. \& Sweeney, T.J. (1992). A Holistic Model for Wellness and Prevention Over the Life Span. Journal of Counselling \& Development, 71 pp. 140-148.

Zukav, G. (1991). The Seat of the Soul. An Inspiring Vision of Humanity's Spiritual Destiny. The Random House Group: London.

Zukav, G. (2001). The Dancing Wu Li Masters. An Overview of the New Physics. HarperCollins : New York. 